\title{
PENGARUH KEDISIPLINAN BELAJAR DAN MINAT BELAJAR TERHADAP PRESTASI BELAJAR SISWA KELAS VIII SMP NEGERI 1 DAGANGAN KABUPATEN MADIUN TAHUN AJARAN 2010/2011
}

\author{
Kardi * \\ Yohni Alimin Prasongko **
}

\begin{abstract}
Abstrak
Penelitian ini bertujuan untuk mengetahui pengaruh kedisiplinan belajar dan minat belajar baik secara bersama-sama maupun secara individual terhadap prestasi belajar siswa kelas VIII SMP Negeri 1 Dagangan Kabupaten Madiun Tahun Ajaran 2010/2011.

Penentuan sampel dalam penelitian ini menggunakan sampel acak (sampel random) yaitu mengambil 45 siswa atau 20,54\% dari jumlah populasi kelas VIII yang berjumlah 219 siswa. Pengumpulan data menggunakan metode teknik angket. Dalam menganalisis data menggunakan analisis dua prediktor dan Uji F.

Uji kedisiplinan belajar $\left(\mathrm{X}_{1}\right) \mathrm{r}_{\mathrm{hit}}=0,492 \geq \mathrm{r}_{\mathrm{tab}}=0,294$ ini berarti $\mathrm{H}_{\mathrm{a}}$ diterima, maka ada pengaruh antara variabel $\mathrm{X}_{1}$ terhadap variabel variabel $\mathrm{Y}$. Uji minat belajar $\left(\mathrm{X}_{2}\right) \mathrm{r}_{\text {hit }}=0,783<\mathrm{r}_{\mathrm{tab}}=0,294$ ini berarti $\mathrm{H}_{\mathrm{a}}$ diterima, maka ada pengaruh antara variabel $\mathrm{X}_{2}$ terhadap variabel variabel $\mathrm{Y}$. Dari hasil uji $\mathrm{F}$. Freg $=32,984 \geq \mathrm{Ftab}=3,22$ ini berarti $\mathrm{H}_{\mathrm{a}}$ diterima sehingga ada pengaruh antara variable $\mathrm{x}$ dalam arti kedisiplinan belajar dan minat belajar terhadap variable Y dalam arti prestasi belajar.

Dari hasil penelitian dapat disimpulkan bahwa ada pengaruh kedisiplinan belajar dan minat belajar terhadap prestasi belajar pada siswa kelas VIII SMP Negeri 1 Dagangan Kabupaten Madiun Tahun Ajaran 2010/2011. Hal ini ditunjukkan dengan perolehan hasil analisis data.
\end{abstract}

Kata Kunci: Kedisiplinan Belajar, Minat Belajar, Pestasi Belajar

* Kardi adalah Dosen Program Studi Bimbingan dan Konseling Fakultas Ilmu Pendidikan IKIP PGRI Madiun

** Yohni Alimin Prasongko adalah Mahasiswa Program Studi Bimbingan dan Konseling Fakultas Ilmu Pendidikan IKIP PGRI Madiun 
Pendahuluan

Banyak pihak yang

memperhatikan berbagai kegiatan dan permasalahan yang ada di bidang pendidikan. Pendidikan memiliki peran penting membantu peserta didik dalam pengembangan dirinya, yaitu pengembangan semua potensi, kecakapan, serta karakteristik pribadinya kearah positif, baik bagi dirinya maupun lingkungannya (Nana Syaodih, 2005:3). Melalui kegiatan pendidikan kualitas sumber daya manusia di suatu negara dapat ditingkatkan.

Berbicara tentang mutu pendidikan tidak akan lepas dari kegiatan belajar. Hasil kegiatan belajar yang diharapkan adalah prestasi belajar yang baik. Setiap individu pasti mendambakan prestasi belajar yang tinggi, baik orang tua, siswa dan lebih- lebih bagi guru. Untuk mencapai prestasi belajar yang optimal tidak lepas dari kondisi-kondisi dimana kemungkinan siswa dapat belajar dengan efektif dan dapat mengembangkan potensi yang ada pada dirinya.

Untuk mencapai prestasi belajar yang baik tidaklah mudah, banyak faktor yang mempengaruhi. Faktor siswa yang memiliki posisi penting demi tercapainya prestasi belajar yang baik, karena siswa merupakan peran utama yang melakukan kegiatan belajar, diperlukan kedisiplinan dan minat belajar.

Dari uraian diatas jelaslah bahwa kedisiplinan belajar dan minat belajar mempunyai peranan dalam pendidikan pada umumnya dan pencapaian prestasi belajar pada khususnya. Minat belajar yang kurang 
dapat dilihat dari sikap siswa yang sering bicara sendiri atau tidak memperhatikan pelajaran yang diberikan oleh guru saat proses belajar. Secara garis besar dapat dijelaskan bahwa prestasi belajar siswa juga dipengaruhi oleh faktor internal dan eksternal. Faktor internal disini adalah kedisiplinan dan minat belajar. Dengan adanya kedisiplinan dan minat belajar, siswa akan dapat memacu prestasi belajar.

Lebih lanjut, Winkel (dalam Vitalis, 2008:8) berpendapat bahwa belajar adalah aktivitas psikis (mental) yang berlangsung dalam interaksi dengan lingkungan yang menghasilkan perubahan-perubahan yang berupa: pengalaman, pengetahuan, nilai dan sikap, serta ketrampilan. Slameto (2010:2) mengartikan belajar ialah suatu proses usaha yang dilakukan seseorang untuk memperoleh suatu perubahan tingkah laku yang baru secara keseluruhan, sebagai hasil pengalamananya sendiri dalam interaksi dengan lingkungannya. Sadiman (2008:26) menjelaskan beberapa tujuan belajar adalah 1) untuk mendapatkan pengetahuan; 2) penanaman konsep dan ketrampilan, dan 3) pembentukan sikap

$$
\text { Faisal Rohman }
$$

mengartikan disiplin belajar adalah suatu kondisi yang tercipta dan terbentuk melalui proses dari serangkaian perilaku seseorang yang sesuai dengan peraturan atau tata tertib untuk memperoleh suatu perubahan tingkah laku yang baru sebagai hasil pengalamannya sendiri dalam interaksi dengan lingkungannya. Faktor-faktor yang mempengaruhi disiplin belajar adalah: 1) Faktor ekstrinsik, yang 
meliputi faktor non-sosial, seperti keadaan udara, suhu udara, waktu, tempat dan alat-alat yang dipakai untuk belajar, dan faktor sosial, yang terdiri atas lingkungan keluarga, lingkungan masyarakat dan lingkungan kelompok;

2) Faktor intrinsik, yang meliputi faktor psikologis, seperti minat, bakat, motivasi, konsentrasi, dan kemampuan kognitif.

Menurut Sofchah

Sulistiyowati (2001:3) beberapa cara yang dapat digunakan siswa agar dapat belajar dengan baik yaitu seorang siswa harus mempunyai sikap disiplin dalam belajar yang meliputi: 1) disiplin dalam menepati jadwal pelajaran, 2) disiplin dalam mengatasi godaan yang akan menunda waktu belajar baik di rumah maupun di sekolah, 3) disiplin terhadap diri sendiri, dan 4) menjaga kondisi fisik agar selalu sehat dan fit.
Disamping faktor internal dari siswa yang berupa kedisiplinan belajar, minat belajar juga mempengaruhi prestasi belajar siswa. Syaiful Bahri Djamarah (2008:166) mengartikan minat adalah kecenderungan yang menetap untuk memperhatikan dan mengenang beberapa aktivitas. Slameto (dalam Djaali, 2007:121) mengartikan suatu rasa suka dan ketertarikan pada suatu hal atau aktivitas, tanpa ada yang menyuruh atau pada dasarnya adalah penerimaan akan suatu hubungan antara diri sendiri dengan sesuatu di luar diri. Dari beberapa definisi tentang minat yang telah dikemukakan oleh para ahli di atas, maka pengertian minat belajar adalah suatu rasa suka atau ketertarikan peserta didik terhadap pelajaran sehingga mendorong peserta didik untuk menguasai pengetahuan dan pengalaman, dalam perubahan 
tingkah laku, baik berupa pengetahuan, sikap dan keterampilan.

Syaiful Bahri Djamarah (2008:167) mengungkapkan ada beberapa cara yang dapat guru lakukan untuk membangkitkan minat anak didik yaitu : 1) membandingkan adanya suatu kebutuhan pada diri anak didik, sehingga guru rela belajar tanpa ada paksaan, 2) menghubungkan bahan pelajaran yang diberikan dengan persoalan pengalaman yang dimiliki anak didik, sehingga anak didik mudah menerima bahan pelajaran, 3) memberikan kesempatan pada anak didik untuk mendapatkan hasil belajar yang baik dengan cara menyediakan lingkungan belajar yang kreatif dan kondusif, dan 4) menggunakan berbagai macam bentuk dan tehnik mengajar dalam konteks perbedaan individual anak didik.
Harapannya, siswa didik yang memiliki kedisiplinan belajar dan minat belajar yang tinggi pada akhirnya dapat meningkatkan prestasi belajar yang ditunjukkan melalui laporan hasil akhir. Siswa tidak akan mendapatkan prestasi belajar yang baik tanpa harus melalui proses belajar. Seperti yang diungkapkan Bloom (dalam Reni dan Hawadi, 2004:68) yang mengartikan prestasi akademik atau prestasi belajar adalah proses belajar yang dialami siswa dan menghasilkan perubahan dalam bidang pengetahuan, pemahaman, penerapan, daya analisis, sintesis, dan evaluasi. Perubahan yang dimaksud dalam hal ini adalah perubahan perilaku sebagai hasil belajar. Perubahan perilaku sebagai hasil belajar mempunyai ciriciri tertentu seperti yang dikemukakan Makmun (dalam Hamid Darmadi, 
2010:186) sebagai berikut: 1) belajar digolongkan menjadi dua faktor perubahan bersifat intensional, dalam yaitu faktor internal dan faktor arti pengalaman atau praktek latihan itu eksternal. Faktor internal meliputi dengan sengaja dan disadari dilakukan faktor jasmaniah yang terdiri dari dan bukan secara kebetulan, 2) faktor kesehatan dan cacat tubuh yang perubahan bersifat positif, dalam arti dialami, dan faktor psikologis yang sesuai dengan yang diharapkan atau terdiri dari intelegensi, perhatian, kriteria keberhasilan, dari segi peserta minat, bakat, motif, kematangan, didik maupun dari segi guru, dan 3) kesiapan, dan faktor kelelahan. Faktor perubahan bersifat efektif, dalam arti eksternal meliputi faktor keluarga, perubahan hasil belajar itu relatif tetap, faktor sekolah, dan factor lingkungan dan setiap saat diperlukan dapat diproduksi dan dipergunakan, seperti dalam pemecahan masalah, ujian, maupun dalam penyesuaian diri dalam kehidupan sehari-hari dalam rangka mempertahankan kelangsungan hidupnya.

Secara ringkas, Supri Wahyudi Utomo dan Satrijo Budi Wibowo (2007:127) mengungkapkan faktorfaktor yang mempengaruhi prestasi masyarakat.

Berdasarkan uraian tersebut, peneliti merumuskan masalah penelitian sebagai berikut: 1) Apakah ada pengaruh kedisiplinan belajar terhadap prestasi belajar pada siswa kelas VIII SMP Negeri 1 Dagangan Kabupaten Madiun Tahun Ajaran 2010/2011, 2) Apakah ada pengaruh minat belajar terhadap prestasi belajar pada siswa kelas VIII SMP Negeri 1 
Dagangan Kabupaten Madiun Tahun Ajaran 2010/2011, dan 3) Apakah ada pengaruh kedisiplinan belajar dan minat belajar terhadap prestasi belajar pada siswa kelas VIII SMP Negeri 1 Dagangan Kabupaten Madiun Tahun Ajaran 2010/2011.

\section{Metode Penelitian}

Metode yang digunakan dalam penelitian ini adalah metode deskriptif korelasi Ex post facto, yaitu suatu penelitian ilmiah yang penelitinya tidak dapat secara langsung memanipulasi dan mengendalikan satu atau lebih variabel bebas serta mengamati variabel terikat untuk melihat perbedaan yang sesuai dengan menipulasi variabel-variabel tersebut (Donald Ary dalam Ibadullah 2009:14).
Penelitian ini dilaksanakan di Sekolah Menengah Pertama Negeri 1 Dagangan Kabupaten Madiun yang beralamatkan di jalan Raya DungusDagangan, Desa Banjarsari Kulon, Kecamatan Dagangan, Kabupaten Madiun.

Populasi penelitian ini adalah siswa kelas VIII SMP Negeri 1 Dagangan Kabupaten Madiun tahun pelajaran 2010/2011 yang berjumlah 219 siswa.

Penetapan sampel penelitian menggunakan teknik random sampling atau sampling acak. Sampel penelitian ini berjumlah 45 siswa dari jumlah anggota populasi 219 orang siswa atau sekitar 20,54\%.

Dalam penelitian ini teknik pengumpulan data menggunakan teknik angket dan dokumentasi. Adapun metode angket yang 
digunakan peneliti dalam penelitian ini adalah angket tertutup dalam bentuk pilihan ganda yaitu responden mimilih jawaban yang disediakan dengan pilihan jawaban a (selalu), b (sering), c (kadang-kadang), d (tidak pernah). Jumlah item untuk masing-masing variabel sama yaitu 20 item sehingga total item pertanyaan pada angket adalah 40, sedangkan dokumentasi digunakan untuk mengumpulkan daftar nama siswa dan data prestasi belajar siswa melalui leger atau rapor.

Uji validitas dalam penelitian ini menggunakan teknik statistik dengan koefisien korelasi product moment. Untuk mengetahui tingkat kestabilan alat ukur dilakukan uji reliabilitas dengan menggunakan rumus alpha. Analisis data menggunakan teknik statistik, yaitu menggunakan rumus “regresi dua prediktor". Sedangkan untuk menguji keberartian koefisien regresi secara keseluruhan digunakan uji F. Hasil F-hitung tersebut dikonsultasikan dengan F-tabel dengan kaidah apabila F-hitung > dari F-tabel maka korelasi tersebut signifikan dan jika F- hitung < F-tabel maka korelasi tersebut tidak signifikan.

\section{Hasil Penelitian}

\section{Deskripsi Data}

a. Deskripsi Skor kedisiplinan belajar diperoleh hasil Mean = 53,77, Median = 54,535, Modus $=56,065$ dan Standar deviasi $=168,794$. rentang kelas yaitu $(65-36=29)$. Dengan ditentukan $(\mathrm{i})=6$, maka $\mathrm{P}=5$ 
Tabel 1. Skala Interval

\begin{tabular}{|cc|c|c|}
\hline $\begin{array}{l}\text { K } \\
\mathrm{e}\end{array}$ & Nilai & $x$ \\
\hline $\mathrm{d}$ & $66-70$ & 6 & 67 \\
\hline $\mathrm{i}$ & $61-65$ & 11 & 62 \\
\hline $\mathrm{s}$ & $56-60$ & 9 & 57 \\
\hline $\mathrm{i}$ & $50-55$ & 8 & 52 \\
\hline $\mathrm{p}$ & $45-49$ & 9 & 47 \\
\hline 1 & $40-44$ & 2 & 42 \\
\hline $\mathrm{i}$ & 45 & 327 \\
\hline
\end{tabular}

nan Belajar

\begin{tabular}{|c|c|c|}
\hline Nilai & $f$ & $x$ \\
\hline $61-65$ & 6 & 63 \\
\hline $56-60$ & 14 & 58 \\
\hline $51-55$ & 13 & 53 \\
\hline $46-50$ & 7 & 48 \\
\hline $41-45$ & 3 & 43 \\
\hline $36-40$ & 2 & 38 \\
\hline & 45 & 303 \\
\hline
\end{tabular}

b. Deskripsi Skor minat belajar siswa kelas VIII SMP Negeri 1 Dagangan Kabupaten Madiun Tahun Ajaran 2010/2011 diperoleh hasil Mean $=56$, Median $=57,44$, Modus $=$ 60,32 dan Standar deviasi = 156,901. rentang kelas yaitu $(68-40=28)$. Dengan ditentukan $(\mathrm{i})=6$, maka $\mathrm{P}=5$

Tabel 2. Skor Minat Belajar

c. Deskripsi Skor prestasi belajar siswa kelas VIII SMP Negeri 1 Dagangan Kabupaten Madiun Tahun Ajaran 2010/2011 diperoleh hasil Mean $=81,333$, Median $=81,089$, Modus $=$ 80,601 dan Standar deviasi = 228,389. Rentang kelas yaitu $(90-75=15)$. Dengan ditentukan $(\mathrm{i})=6$, maka $\mathrm{P}=3$

Tabel 3. Prestasi Belajar Nilai 


\begin{tabular}{|c|c|c|}
\hline $73-75$ & 3 & 74 \\
\hline $76-78$ & 10 & 77 \\
\hline $79-81$ & 11 & 80 \\
\hline $82-84$ & 9 & 83 \\
\hline $85-87$ & 9 & 86 \\
\hline $88-90$ & 3 & 89 \\
\hline & 45 & 489 \\
\hline
\end{tabular}

terhadap pestasi belajar menunjukkan harga $r x_{2} y=0,783 . \quad$ setelah dikonsultasikan dengan $\mathrm{r}$ tabel,

\section{Hasil Analisa Data}

1. Hasil analisis data tentang pengaruh kedisiplinan belajar terhadap prestasi belajar menunjukkan harga $r x_{1} y=0,492 . \quad$ Setelah dikonsultasikan dengan r-tabel, untuk mengetahui signifikan atau tidak signifikan, maka harga $r$-hitung $=0,492>$ r-tabel $=0,294$, untuk $\mathrm{N}$ sebanyak 45, sehingga dinyatakan signifikan, artinya kedisiplinan belajar ada pengaruh terhadap presatasi belajar siswa.

2. Hasil analisis data tentang pengaruh minat belajar untuk mengetahui signifikan atau tidak signifikan, maka harga $\mathrm{r}$-hitung $=0,783>$ r-tabel $=0,294$, untuk $\mathrm{N}$ sebanyak 45 . sehingga dinyatakan signifikan, artinya minat belajar ada pengaruh terhadap presatasi belajar siswa.

3. Hasil analisis data tentang kedisiplinan belajar dan minat belajar terhadap prestasi belajar menunjukkan bahwa F-reg = 32,984, untuk mengetahui apakah harga F-reg sebesar 32,984 itu signifikan atau tidak signifikan, maka dikonsultasikan dengan nilai F- 
tabel. Harga F-tabel adalah

3,22 . sehingga dinyatakan signifikan, artinya kedisiplinan belajar dan minat belajar ada pengaruh terhadap presatasi belajar siswa.

\section{Simpulan dan Saran}

Berdasarkan hasil analisis data, maka dapat disimpulkan :

1. Ada pengaruh kedisiplinan belajar terhadap prestasi belajar siswa kelas VIII SMP Negeri 1 Dagangan Kabupaten Madiun Tahun Ajaran 2010/2011.

2. Ada pengaruh minat belajar terhadap prestasi belajar siswa kelas VIII SMP Negeri 1 Dagangan Kabupaten Madiun Tahun Ajaran 2010/2011.

3. Ada pengaruh kedisiplinan belajar dan minat belajar terhadap prestasi belajar siswa kelas VIII SMP
Negeri 1 Dagangan Kabupaten

Madiun Tahun Ajaran 2010/2011. 
Berdasarkan hasil penelitian, maka saran yang dapat diberikan adalah:

1. Pihak sekolah hendaknya lebih meningkatkan penegakan kedisiplinan sekolah. Khususnya bagi siswa. Perlunya sanksi yang tegas untuk pelanggaran kedisiplinan bagi siswa yang melanggarGuru dan Konselor Sekolah.

2. Pihak guru dapat menggunakan metode pembelajaran yang bervariasi, sehingga mengurangi tingkat kebosanan dan meningkatkan kedisiplinan belajar dan minat belajar siswa dalam mengikuti pelajaran.

3. Orang tua hendaknya meningkatkan kualitas cara mendidik anak dengan memperhatikan keteraturan siswa belajar di rumah dan menyediakan fasilitas belajar yang memadai berupa ruang belajar.

4. siswa hendaknya mampu menerapkan disiplin belajar untuk mencapai prestasi belajar yang lebih baik lagi dan menumbuhkan minat belajar yang lebih, untuk mencapi prestasi belajar yang baik.

\section{Daftar Pustaka}

Dahlia Novarianing Asri. 2008. Pemahaman Individu. Diktat Pembelajaran Program Studi Bimbingan dan Konseling, Fakultas Ilmu Pendidikan IKIP PGRI Madiun

Djaali. 2007. Psikologi Pendidikan. Jakarta: Bumi Aksara

Faisal

Rahman. http://faisalrohman.blogspot.com/ 2009/03/pengaruh-disiplin-danmotivasi-belajar.html (diakses tanggal 25 februari $2011 \mathrm{jm}$ 10.30)

Hamid Darmaji. 2010. Kemampuan Dasar Mengajar (Landasan Konsep dan Implementasi). Bandung: Alvabeta 
Husaini Usman dan Purnomo Setiyadi A. 2006. Pengantar Statistika. Jakarta: Balai Pustaka

Ibadullah Malawi. 2009. Penelitian Pendidikan. Diktat Pembelajaran Program Studi Bimbingan dan Konseling, Fakultas Ilmu Pendidikan IKIP PGRI Madiun

Nana Syaodih Sukmadinata. 2007. Bimbingan dan Konseling Dalam Praktek. Bandung: Maestro

Oemar Hamalik. 2004. Proses Belajar Mengajar. Jakarta: Bumu Aksara

Reni Akbar dan Hawadi. 2004. Akselerasi. Jakarta: Gramedia Widiasarana Indonesia

Sardiman. 2008. Interaksi dan Motifasi Belajar Mengajar. Jakarta: Raja Grafindo Pesada

Slameto. 2010. Belajar dan FaktorFaktor yang Mempengaruhinya. Jakarta: Rineka Cipta

Soebiyanto Dkk. 2009. Modul Bimbingan dan Konseling. Tim MGMP $2009 \quad$ Kabupaten Magetan: Prastowo Sejati

Sofchah Sulistyowati. 2001. Cara Belajar Yang Efektif dan Efisien. Pekalongan: Cinta Ilmu

Suharsimi Arikunto. 2006. Prosedur Penelitian Suatu Pendekatan Praktek. Jakarta: Rineka Cipta

Supri Wahyu Utomo dan Satrijo Budiwibowo. 2007. Penerapan
Metode Talking Chip Dalam Pembelajaran Kooperatif Guna Meningkatkan Prestasi Belajar Kewiausahaan di SMK (SMEA 1) Madiun. Jurnal Pendidikan. Madiun: IKIP PGRI Madiun

Syaiful Bahri Djamarah. 2008. Psikologi Belajar. Jakarta: Rineka Cipta

Vitalis. 2008. Diagnosis Kesulitan dan Kegagalan Belajar. Diktat Pembelajaran Program Studi Bimbingan dan Konseling, Fakultas Ilmu Pendidikan IKIP PGRI Madiun 